Volume 4 No. 1, Juni 2019

P ISSN 2442-594X | E ISSN 2579-5708

http://journal.iainlangsa.ac.id/index.php/tibyan

DOI: $10.32505 /$ tibyan.v4i1.827

\title{
HAKEKAT TAFSIR SURAT AL-FATIHAH \\ (Pemahaman Hakikat Ibadah Kepada Allah Swt Dalam Menghadapi Persoalan Kehidupan)
}

The Prosperity Of Al-Fatihah Letters (Understanding the Nature of Worship to God Almighty in Facing Life Problems)

\section{Safria Andy}

Dosen Tetap Fakultas Ushuluddin dan Studi Islam UIN-SU

al.andawi53@gmail.com

\begin{abstract}
Surah al-Fatihah is a special letter of 114 letters in the Qur'an. This privilege has placed it as a letter that was recited in a number of times and became part of the pillars of prayer. In the sunglasses of tasawauf, al-Fatihah which is believed by one verse, namely Iyyaka Nabudu wa Iyyaka Nastain is the key in the straightness of a servant's faith to only Allah SWT, and plead with Him. The application in Sufism is the closeness of a servant to Allah who is intimately intertwined, thus creating a deep sense of love. The love of a servant to Allah SWT, has placed himself in the ability of himself to answer various problems and solve problems in his life. The above study is a study that is rarely achieved and owned by the servants of Allah, so that the Fatihah does not color his life in facing problems and problems. Therefore, discussing the nature of surat al-Fatihah as a key in creating a servant's closeness in worshiping Allah Almighty to be able to face life's problems and be able to realize happiness in the world and in the hereafter. Happiness is achieved by requiring our Islamic through intact in worshiping God Almighty, as God.
\end{abstract}

Keywords: Al-Fatiha, Nature, Worship, World Happiness and the Hereafter.

\begin{abstract}
Abstrak
Surat al-Fatihah merupakan surat yang istimewa dari 114 surat dalam Alquran. Keistimewaan tersebut telah menempatkannya sebagai surat yang dibacakan dalam berulanag-ulang dan menjadi bagian dari rukun sholat. Dalam kacamata tasawauf, al-Fatihah yang diimami oleh satu ayat, yaitu Iyyaka Năbudu wa Iyyaka Nastain merupakan kunci dalam kelurusan keimanan seorang hamba untuk hanya menuhankan Allah Swt., dan memohon kepada-Nya. Permohonan dalam tasawuf adalah kedekatan seorang hamba
\end{abstract}


kepada Allah Swt yang terjalin dengan erat, sehingga menciptakan rasa cinta yang mendalam.Kecintaan seorang hamba kepada Allah Swt., telah menempatkan dirinya kepada kemampuan diri dalam menjawab berbagai persoalan dan menyelesaikan permasalahan hidupnya. Kajian di atas yang merupakan kajian yang jarang dicapai dan dimiliki oleh para hamba Allah Swt., sehingga al-Fatihah tersebut tidak mewarnai kehidupannya dalam menghadapai persoalan dan permasalahan. Oleh karena itu, melakukan pembahasan kajian hakekat surat al-Fatihah sebagai kunci dalam menciptakan kedekatan diri seorang hamba dalam beribadah kepada Allah Swt untu mampu menghadapi persoalan kehidupan dan akan mampu mewujudkan kebahagiaan di dunia dan di akhirat.Kebahagiaan tercapai dengan mengutuhkan keislaman kita melalui penerpan secara utuh dalam menuhankan Allah Swt., sebagai Tuhannya.

Kata Kunci: Al-Fatihah, Hakekat, Ibadah, Kebahagiaan Dunia dan Akhirat.

\section{Pendahuluan}

Sebagian seorang hamba dalam melaksanakan wujud peribadatannya selalu memiliki kebimbangan dalam menerima hakikat dari ibadah yang dilakukannya, sehingga ibadahnya belum mampu menjawab segala persoalan dalam kehidupannya.Apakah ibadah tersebut telah memberikan kedamaian dalam kehidupannya.Apakah ibadah tersebut telah memberikan kemudahan di dalam menghadapi segala persoalan dan permasalahan dalam kehidupannya. Oleh karena itu, tulisan ini akan mencoba menelusuri jawaban dari pertanyaan di atas melalui kupasan kajian surat al-Fatihah yang dikaji dari hakikatnya.

Hakikat ibadah sejatinya adalah tujuan dari ibadah yang dikerjakannya, yaitu menjadikan Allah sebagai satu-satunya sosok yang dituhankan dan sosok yang diminta pertolongan.Al-Fatihah adalah salah satu surat dari 114 surat yang ada di dalam Alquran. Sebagian ulama dalam Tafsir Ibn Katsir mengungkapkan bahwa al-Fatihah merupakan surat yang memiliki kandungan makna yang mampu membimbing hamba Allah Swt., untuk menemui predikat dirinya sebagai hamba sejati dari Allah Swt., yang Mahasuci. Yahya bin Abi Katsir ${ }^{1}$ menamainya dengan al-Kafiyah (yang mencukupi) berdasarakan keterangan dalam beberapa hadits mursal yang menyatakan, "Ummul Qur'an sebagai pengganti dari selain nama-nama al-Fatihah. Selain nama-nama alFatihah itu, tidak ada lagi nama sebagai penggantinya."

Oleh karena itu, dari pernyataan dua alinea di atas memberikan inspirasi kepada penulis untuk membahas, Pandangan Ahli Tafsir tentang pengertian Surat al-Fatihah, Hakekat Keutamaannya, Tafsir Surat al-Fatihah, dan Analisa Isi kandungan al-Fatihah sebagai Kunci Seorang Hamba dalam Menghadapi Persoalan Kehidupan dengan kedekatan diri Kepada Allah Swt; Kemudahan dalam Mencapai Kedamaian Hidup

${ }^{1}$ Muhammad Nasib ar-Rifa'i, Ringkasan Tafsir IBNU KATSIR (Surah al-Fatihah- an-Nisaa), Jilid 1, terj. Syihabuddin, (Jakarta: Gema Insani, 2012), Cet. Pertama, h. 44. 
dengan Kemudahan dalam Menghadapi Berbagai Persoalan dan Permasalahan. Semoga niat dan tujuan penulisan tulisan ini diberkati Allah Swt. Aamiiin.

\section{Pandangan Ahli Tafsir tentangPengertian Surat al-Fatihah}

Surat al-Fatihah adalah surat pertama yang tercantum di dalam Alquran. AlFatihah juga merupakan surat yang digunakan dalam setiap sholat baik wajib maupun sunnat. Secara umum juga dipahami bahwa al-Fatihah adalah induknya Alquran, dengan bahasa lain disebut Ummul Qur'an. Untuk menguatkan pemahaman tentang surat al-Fatihah, dapat dilihat bagaimana pandangan ahli tafsir yaitu pandangan seorang yang ahli dalam menafsirkan surat dan ayat yang akan membahas tentang pengertian surat al-Fatihah.

\section{Ibn Katsir}

Al-Fatihah dinamai Fatihatul- Kitab karena merupakan pembuka tulisan AlKitab.Dengan surah tersebut juga disertakan (wajib) dalam setiap sholat saat dimulainya. Al-Fatihah memiliki nama lain. Nama-namanya berupa Ummul-Kitab dan Ummul-Qur'an, karena ia memiliki makna-makna kandungan Alquran yang berkiblat kepada al-Fatihah. Disebut juga nama lainnya dengan sebutan as-Sabul-Matsani dan Alquranul-Azhim. Pernyataan tersebut telah dijelaskan di dalam hadits sahih yang diriwayatkan dan disahihkan oleh Tirmizi dari Abu Hurairah, yang isinya, "Segala puji bagi Allah Tuhan Semesta Alam... adalah Ummul-Kitab, Sabul-Matsani, dan Alquranul Azhim."

Nama lain dari al-Fatihah adalah al-Hamdu dan as-Shalat, karena Nabi Muhammad Saw., pernah menyatakan dalam sabdanya dari Allah Swt., yang isinya, "Shalat dibagi dua antara Aku dan Hamba-Ku. Apabila hamba-Ku mengatakan, 'Segala puji bagi Allah Rabb semesta alam,' maka Allah berfirman,'Hamba-Ku memuji-Ku.'Disebut as-Shalat, karena al-Fatihah merupakan bagian dari rukun shalat. Al-Fatihah juga disebut dengan asy-Syifa, karena ia dapat menyembuhkan dari segala racun. Hal tersebut telah disampaikan oleh ad-Darimi dari Abu Said berupa hadits yang diriwayatkan secara marfu dan disebut juga dengan sebutan ar-Ruqyah, sebagai jampi.Hadits tersebut diriwayatkan oleh Abu Said al-Khudri. ${ }^{3}$ Artinya, ${ }^{4}$ inti yang lain dari tujuan pelaksanaan shalat adalah untuk memuji Allah Swt., sehingga hamba-Nya terselamatkan dari godaan syaithan yang memberlakukan fasilitas dunia sebagai alatnya. Oleh karena itu, surat al-Fatihah menjadi bagian dari rukun shalat. Lebih jelas lagi kajian utama yang menjadi surat al-Fatihah merupakan bagian dari shalat tertera di dalam ayat yang berbunyi Iyyaka Nabudu wa Iyyaka Nastain dan akan dijelaskan dalam analisa pandangan tafsir tentang tafsir surat al-Fatihah.

\footnotetext{
${ }^{2}$ Lihat., Muhammad Nasib ar-Rifă, Ringkasan.., h. 43-44.

${ }^{3}$ Lihat, Ibid., h. 44

${ }^{4}$ Menurut hemat Penulis
} 
Al-Fatihah juga disebut dengan Asasul-Qura'an, telah dijelaskan oleh asy-Syabi dari Ibnu Abbas bahwa, "Dasar al-Fatihah adalah bismillahir-rahmanir-rahim"."Yahya bin Abi Katsir menamainya dengan al-Kafiyah (yang mencukupi) berdasarakan keterangan dalam beberapa hadits mursal yang menyatakan, "Ummul Qur'an sebagai pengganti dari selain nama-nama al-Fatihah. Selain nama-nama al-Fatihah tersebut, tidak ada lagi nama sebagai penggantinya."KKajian Yahya di atas insya Allah akan dijelaskandibahasan berikutnya dalam analisa di antaranya, sebagai perwakilan makna dari seluruh surat di dalam Alquran yang diwakili oleh ayat Iyyaka Nabudu wa Iyyaka Nastain. hal tersebut akan menjadi inti utama dari inti wujud beribadah seorang hamba kepada Allah Swt.

\section{Tafsir Al-Azhar}

A-l-Fatihah artinya pembukaan. Surah ini pun dinamai Fathatul-Kitab, yang berarti pembukaan kitab, karena Alquran dimulai dengan surat al-Fatihah. Surat tersebut mulai ditulis di dalam Mushaf(Alquran) walaupun surat tersebut bukan surat atau ayat pertama yang diturunkan oleh Allah kepada Nabi Muhammad Saw. Namanya telah masyhur dari masa nubuwwah. ${ }^{7}$ Ia diturunkan di Mekkah.

Menurut suatu riwayat dari Abu Syaibah di dalam al-Mushanaf dan Abu Nuaim dan al-Baihaqi di dalam Dalailun- Nubuwwah, dan hadits Amer bin Syurahbil bahwa setelah Rasulullah saw, mengeluhkan pengalamannya di dalam gua itu setelah menerima wahyu pertama, kepada Khadijah kepada Waraqah. Maka, beliau ceritakan kepadanya bahwa apabila dia telah memencil seorang diri, didengarnya suara dari belakangnya, "Ya, Muhammad, ya Muhammad, ya Muhammad! Mendengar suara itu, akupun lari." Maka, berkatalah Waraqah, “ Jangan engkau berbuat begitu, tetapi jika engkau dengar suara itu, tetap tenanglah engkau, sehingga dapat engkau dengar apa lanjutan perkataannya itu." Selanjutnya, Rasulullah saw, berkata, "Maka dating lagi dia dan terdengar lagi suara itu, 'ya Muhammad!Katakanlah, 'Bismillahir-rahmanirrahim, alhamdulillahi Rabbil Alamin.'Hingga sampai kepada waladhdhaalin. 'Demikian hadits itu. ${ }^{8}$

Kesimpulan penulis dari paparan kajian Hamka di atas menyatakan bahwa surat al-Fatihah di saat setelah menerima wahyu pertama merupakan surat yang juga telah turun di masa tersebut dan layak diletakkan di pembukaan Alquran alias berada di surat pertama dalam 114 surat lainnya.

\section{Tafsir Jalalain}

Surat Al-Fatihah diturunkan di Mekkah; jumlah ayatnya ada tujuh berikut basmallah, menurut pendapat yang menganggapnya sebagai salah satu ayat

${ }^{5}$ Penulis menerjemahkannya bahwa setiap perbuatan seorang hamba harus didasari oleh karena Allah Swt., yang memiliki Segala Kasih dan Segala Sayang-Nya, sehingga seluruh persoalan dan permasalahan yang dihadapi akan mudah dijawab dan diselesaikan.

${ }^{6}$ Lihat., Muhammad Nasib ar-Rifă, Ringkasan..., h. 44

${ }^{7}$ Lihat., Hamka, Tafsir Al-Azhar, Jilid. 1 (Jakarta: Gema Insani, 2015), cet. Pertama, h. 57.

${ }^{8}$ Hamka, Tafsir.., Jilid. 1. h. 57-58 
daripadanya, sedangkan ayat yang ketujuh menurutnya ialah mulai dari siratal lazina sampai dengan akhir surat. Jika basmalah dianggap bukan sebagai salah satu ayat dari al-Fatihah, maka ayat ketujuhnya ialah mulai dari gairil magdubi sampai dengan akhir surat. ${ }^{9}$ Berdasarkan anggapan di atas, maka sebelum ayat yang ketujuh diperkirakan adanya kalimat qulu, supaya ayat yang ketujuh tersebut maknanya sejalan dengan ayatayat sebelum ayat Iyyaka Nabudu, yang kesemuanya dianggap sebagai doa dari hambahamba Allah Swt. ${ }^{10}$

Tafsir di atas menjelaskan bahwa surat al-Fatihah diawali dengan basmallah yang menjadi bagian hitungan bilangan ayat dan ditutup dengan ayat ketujuh sirathalladzina..sampai akhir ayat.

\section{Hakikat Keutamaannya}

Imam Ahmad r.a, meriwayatkan dari Abu Hurairah r.a., ia berkata, "Rasulullah Saw., menemui Ubai bin Kaab, namun ia sedang shalat. Rasul berkata, 'Hai Ubai! 'Maka Ubai melirik, namun tidak menyahut. ${ }^{11}$ Nabi berkata, 'Hai Ubai. 'Lalu Ubai mempercepat shalatnya, kemudian beranjak menemui Rasulullah saw, sambil berkata, 'Assalamu'alika, ya Rasulullah.' Rasul menjawab, 'Waalikassalam. Hai Ubai, mengapa kamu tidak menjawab ketika kupanggil?' Ubai menjawab, 'Wahai Rasulullah, sesungguhnya aku sedang shalat.'Nabi bersabda, 'Apakah kamu tidak menemukan dalam ayat yang diwahyukan Allah taala kepadaku yang menyatakan.'Penuhilah seruan Allah dan seruan Rasul apabila Rasul meneyeru kamu kepada sesuatu yang memberi kehidupan kepadamu." (al-Anfal: 24). ${ }^{12}$ Rasul bersabda, 'Sukakah kamu bila kuajari sebuah surah yang tidak diturunkan surat lain yang serupa dengannya di dalam Taurat, Injil, Zabur, dan al-Furqan?' Ubai menjawab, 'Saya suka, wahai Rasulullah.'Beliau bertanya, 'Ap yang kamu baca dalam shalat?'Ubai berkata, 'Maka aku membacakan Ummul-Qur' an kepada beliau.'Beliau bersabda, 'Demi yang jiwaku dalam genggamanNya, Allah tidak menurunkan surah yang setara dengan itu baik dalam Taurat, Injil, Zabur, maupun al-Furqan.Ia merupakan tujuh ayat yang dibaca berulang-ulang. "’13

Dari kajian di atas dapat dilihat bahwa keutamaan surat al-Fatihah adalah surat yang tidak tercantum dalam kitab Allah lain pun kecuali dalam Alquran. Surat yang didasarkan dengan Bismillahir-Rahmanir-Rahim. Surat yang dibacakan secara berulang-ulang (sabul-Matsani) dan surat yang dijadikan sebagai salah satu rukun dalam shalat yang dijelaskan sebelumnya surat yang dibacakan dengan berulang-ulang. Kajian yang paling menarik menurut penulis keistimewaan surat tersebut adalah surat yang dinamai dengan surat al-hamdu, yaitu surat yang terjadi saling memuji antara hamba Allah dengan Allah sendiri.

\footnotetext{
${ }^{9}$ Imam Jalaluddin al-Mahalli dan Imam Jalaluddin as-Suyuti, Tafsir Jalalain, Jilid.1, terj. Bahrun Abu Bakar, (Bandung: Sinar Baru Algensindo, 2010), cet. Kedelapan, h. 1.

${ }^{10}$ Lihat., Imam Jalaluddin al-Mahalli........, Jilid. 1. h. 1.

${ }^{11}$ Muhammad Naseb ar-RifăI, Ringkasan.........., Jilid. 1, h. 44

${ }^{12}$ Muhammad Naseb......., h. 44

${ }^{13}$ Muhammad Naseb..........., h. 44
} 
Hamba Allah Swt., yang paling pandai memuji kepada Allah Swt., adalah Nabi Muhammad Saw., dan terlihat dari nama beliau terdapat di dalam ayat yang tertera dalam surat al-Fatihah, yaitu kata al-hamdu, yang berderivasi dari hamida-yahmadumuhammadun. Kajian tersebut penulis beranikan sebagai korelasi dari surat al-Anfal ayat 24, yang berisi tentang memenuhi seruan Allah Swt., dan Rasulullah Saw., yang menjadi alasan bagi Ubai bin Kaab untuk memutuskan shalatnya demi memenuhi seruan atau panggilan Rasulullah dan menggantikannya setelah pemenuhan panggilan tersebut. ${ }^{14}$

Banyak keutamaan dan keistimewaan surat al-Fatihah, sehingga menjadi bagian yang utama untuk dipegang, diamalkan dan diimplementasikan setiap kegiatan pada kehidupan seorang hamba. Kupasan tersebut akan dijelaskan di dalam analisa yang akan penulis lakukan di sub kajian berikutnya setelah pemaparan tafsir surat al-Fatihah secara singkat.

\section{Tafsir Surat al-Fatihah dan Analisanya}

Dalam kajian tafsir surat al-Fatihah pada tulisan ini, akan bersinggungan dengan kajian tasawuf. Kajian tasawuf di antaranya mengupas tentang hakikat, sebab kajian tersebut mengedepan akhirat daripada dunia.Tujuan yang dilakukan adalah membangun akhlak yang mulia. Kemuliaan akhlak seorang hamba dibangun oleh kedekatannya kepada Allah Swt. Dengan melihat hakikat surat al-Fatihah, maka akan membangun kedekatan diri seorang hamba kepada Allah Swt., dalam beribadah dan mewujudkan akhlak yang mulia. Kandungan inti dalam surat al-Fatihah menurut hemat penulis adalah professionalitas ${ }^{15}$ dan propossionalitas $^{16}$ dalam pemahaman kalimat Iyyaka Nabudu wa Iyyaka Nastain, artinya seorang hamba hanya memahami bahwa tidak ada tempat menyembah dan memohon pertolongan kecuali kepada Allah Swt. Prilaku tersebut akan mengantarkan seorang hamba untuk berakhlak yang mulia, sebab fasilitas dunia tidak mampu menggoyahkan kedekatan dirinya dengan Allah Swt. Untuk lebih jelasnya, akan dipaparkan pada kupasan tentang per-ayat dari surat alFatihah.

\footnotetext{
${ }^{14} \mathrm{Hal}$ tersebut juga dapat diimplementasikan saat ini saat orang tua (yang sudah sepuh terutama dan sakit- sakitan) kita memanggil kita selagi shalat dan memutuskannya, untuk memenuhi panggilan tersebut. Kajian ini terinspirasi dengan ijin Allah melalui pemahaman tafsir dari awal surat al-Isra ayat 23; bahwa Allah telah menentukan kepada kita untuk tidak menyembah tuhan lain selain diri-Nya dan kepada orang tua-mu, maka berbuat baiklah. Mengedepankan panggilannya karena Allah adalah bagian dari firman Allah dan pembelajaran dari Rasulullah.Dua hal yang menyebabkan mengedepankan panggilan orang tua dari sholat adalah pertama, untuk tidak menyakiti perasaannya bila mereka tidak tahu bila kita sedang shalat. Kedua, untuk tidak mencelakakan mereka di kala mereka sudah sepuh, sakit dan susuah berjalan sehingga bila tidak kita dahului panggilan mereka akan terjadi sesuatu yang tidak kita inginkan dan telah melakukan keburukan bagi orang tua. Keburukan tersebut bertentangan dengan perintah Allah dalam surat al-Isra ayat 23 dan sabda Rasulullah untuk melakukan kebaikan kepada Ibu, Ibu, Ibu dan Bapak kita. Wa Allahu Avlam.

${ }^{15}$ Mensituasikan pemhamannya tentang surat al-Fatihah dalam kehidupan sehari-hari.

${ }^{16}$ Memposisikan pemahaman tersebut dalam pengimplementasian prilaku seorang hamba dalam kehidupan sehari-hari.
} 


\section{Bismillahir-rahmanir-rahim}

Syekh Muhammad Abduh menyatakan tentang surat al-Fatihah dalam tafsirnya, bahwa Alquran adalah imam dan ikutan kita, maka Alquran dimulai dengan kalimat ata ayatbismillāhir-rahmānir-rahīm, pernyataan tersebut merupakan satu petunjuk bagi kita agar sekalian amalan kita dimulai dengan ayat tersebut, karena menurut kebiasaan pada bangsa Arab, apabila hendak mengerjakan sesuatu pekerjaan yang diperintahkan oleh seorang raja ataupun pembesar, maka sewaktu melakukan pekerjaan, ia berkata: "saya kerjakan pekerjaan ini dengan nama Raja atau pembesar Polan." Jadi makna bismillāhir-rahmānir-rahīm "Saya mulai mengerjakan pekerjaan ini dengan nama Allah", ataupun "Saya mulai pekerjaan ini berlepas dari pengakuan bahwa ada dengan nama saya sendiri, hanya semata-mata dengan nama Allah, karena adalah saya semata-mata meminta bantuan dan pertolongan dari pada-Nya dan mengharap anugrah-Nya. Jika tidak karena itu, tentu saja tak kuasa mengerjakannya ataupun saya tidak kerjakan". ${ }^{17}$

Makna bismillāhir-rahmānir-rahīm yang ada pada al-Fatihah "Bahwasanya sekalian hukum-hukum, ayat-ayat dan lain-lain yang sudah ditetapkan pada Alquran, semuanya bagi Allah Swt., dan dari pada-Nya. Allah nama Tuhan yang disembah dengan sebesar-besarnya dan lafaz Allah, sudah khusus dalam bahasa Arab tertentu pada Tuhan yang menjadikan langit dan bumi, Tuhan semesta Alam. Al-Rahmān, ialah sifat Allah yang berarti menganugrahkan nikmat yang besar-besar.Al-Rahīm juga sifat Allah yang berarti menganugrahkan nikmat yang halus-halus. Menurut Abduh, antara keduanya memiliki perbedaan yang amat besar. Menurut bahasa Arab, tiap-tiap kalimat seperti al-Rahmān dan al-Rahīm adalah menunjukkan sifat yang tetap.Oleh karena itu, makna al-Rahmān adalah melimpahkan nikmat dan karunia.Sedangkan makna al-Rahīm adalah bahwa rahmat Allah itu adalah sifat yang tetap dan yang wajib. $^{18}$

Kata Allah merupakan nama untuk Rabb. Dikatakan bahwa Allah adalah alIsmul-a'zham (nama yang paling agung), karena nama itu menyandang segala macam sifat. Sebagaimana firman Allah: "huwallāhulladzi lā ilāha illa hu 'ãlimulghaibi wassyahādah huwarrahmānurrahīm. "' Dengan demikian, semua nama-nama yang baik telah menjadi sifat-Nya. Dalam kitab shahih al-Bukhari dan Muslim diriwayatkan dari Abu Hurairah ra., bahwa Rasulullah Saw., telah bersabda: "inna lillāhi tis'atan wa tis'iinā isman, miatan illa wāhidan man ahshoha dakhalaljannah."

Nama Allah merupakan nama yang tidak diberikan kepada siapa pun selain diriNya, yang Mahasuci dan Mahatinggi. Oleh karena itu, dalam bahasa Arab tidak diketahui dari kata apa nama-Nya itu berasal. Di antara para ahli nahwu ada yang menyatakan bahwa nama itu (Allah) adalah ismun jamīd, yaitu nama yang tidak mempunyai kata dasar. Al-Khalil dan Sibawaih diriwayatkan bahwa "Alif" dan "lam"

\footnotetext{
${ }^{17}$ Lihat, 'Abdullah bin Muhammad bin 'Abdurrahman bin Ishaq Alu Syaikh (Pentahqiq/Peneliti), Tafsir Ibn Katsir,Jild. I, terj. (Bogor : Pustaka Imam Asy-Syafi’I, 2004), cet. V,h. 42-43

${ }^{18}$ Lihat Ibid., h. 43

${ }^{19}$ Q.S. al-Hasyr: 22.
} 
dalam kata "Allah" merupakan suatu yang lazim (tak terpisahkan). Al-Khaththabi mengatakan: "Tidakkah anda menyadari bahwa anda dapat menyerukan "Ya Allah" dan tidak dapat menyerukan "Ya al-Rahmān". Kalau kata "Allah" bukan kata yang masih asli, maka tidak boleh memasukkan huruf nida' (seruan) terhadap "alif" dan "lam". Ada juga yang berpendapat bahwa kata Allah memiliki kata dasar. Adapun namaal-Rahmān dan al-Rahīm. Al-Qurthubi mengatakan, dalil yang menunjukkan bahwa nama ini Musytaq ${ }^{20}$ adalah hadis riwayat at-Tarmidzi, dari Abdurrahman bin Auf ra., bahwa ia pernah mendengar Rasulullah Saw., bersabda: "Qālallāhu ta'āla anā al-Rahmān khalaqturrahīma wasyaqaqtu lahā isman min ismī faman washolaha washoltuhu waman qatho'aha qatha'tuhu" "Allah Ta'ala berfirman: Aku adalah alRahmān, Aku telah menciptakan rahim (rahim-kerabat). Aku telah menjadikan untuknya nama dari nama-Ku. Barangsipa yang menyambungnya, maka Aku akan menyambungnya. Barangsiapa yang memutuskannya maka Aku pun memutuskannya. ${ }^{21}$

Abu 'Ali al-Farisi mengatakan: "Al-Rahmān merupakan nama yang bersifat umum meliputi segala macam bentuk rahmat, nama yang dikhususkan bagi Allah 'Azza wajalla semata. Sedangkan al-Rahìm, memberikan kasih sayang hanya kepada orang-orang yang beriman." Berkenaan dengan hal tersebut, Allah Swt., berfirman: “wakāna bilmuminīna rahīman" "Dan Dia- yang yang Mahapenyayang kepada orangorang yang beriman." 22 Adapun Ibnu al-Mubarrak mengatakan: "Al-Rahman yaitu jika dimintai, maka Dia akan memberi, sedangkan al-Rahim yaitu, jika permohonan tidak diajukan kepada-Nya, maka Dia akan murka. Sebagaimana dalam hadis riwayat atTirmidzi dan Ibnu Majah dari Abu Shalih al-Farisi al-Khuzi, dari Abu Hurairah ra.,, bahwa Rasulullah Saw., bersabda: "man lam yasalillaha yaghdhob 'alaihi"’3

Nama al-Rahmān hanya ditujukan kepada Allah semata dan tidak diberikan kepada selain diri-Nya.Sebagaimana Allah berfirman dalam QS. Al-Isrā:110. Oleh karena itu, Musailamah al-Kadzdzāb menyebut dirinya dengan sebutan Rahmān alYamamah, maka Allah-pun memakaikannya pakaian kebohongan dan membongkarnya, sehingga ia tidak di panggil melainkan dengan sebutan Musailamah si pendusta. Adapun al-Rahìm, Allah tidak pernah menyebutkan kata tersebut kecuali kepada diriNya.Sebagaimana firman Allah dalam QS. At-Taubah: 128. Dapat disimpulkan bahwa di antara nama-nama Allah ada yang disebutkan untuk selain diri-Nya dan ada pula yang tidak disebutkan untuk selain diri-Nya, misalnya nama Allah, al-Rahman, alKhaliq, al-Razzaq. Oleh karena itu, Ia memulai dengan nama Allah dan menyifati-Nya dengan al-Rahman, karena al-Rahman lebih khusus daripada al-Rahim.

Dengan menempatkan Allah Swt dalam kehidupan seorang hamba di setiap aktivitas hidupnya dan memperoleh kasih sayang-Nya akan memberikan kemudahan-

\footnotetext{
${ }^{20}$ Musytaq/isim (kata benda) yang terbentuk dari fi'ilnya (kata kerjanya). Contoh: minsyarun (gergaji) berasal dari nasyara-yansyaru (menggergaji)

${ }^{21}$ Lihat, 'Abdullah bin Muhammad bin 'Abdurrahman bin Ishaq Alu Syaikh (Pentahqiq/Peneliti), Tafsir Ibn Katsir,Jild. I, terj. (Bogor : Pustaka Imam Asy-Syafi'I, 2004), cet. V,h. 21-22.

${ }^{22}$ Q.S. al-Ahzab: 43

${ }^{23}$ Lihat, Ibid., h. 22
} 
kemudahan dalam menghadapi segala rintangan dan menempatkannya kepada pemahaman tentang arti kebenaran, yaitu bahwa semua milik Allah Swt., dan kembali kepada-Nya. Pemahaman kebenaran tersebut pada diri seorang hamba akan melancarkan segala urusan yang dilakukannya dan memberikan keyakinan yang tinggi yang senantiasa didukung oleh Allah Swt.

Bismillāhir-rahmānir-rahīm memiliki makna yang khusus bagi seorang hamba dan tidak bisa untuk diwakilkan, artinya masing masing seorang hamba harus menempatkan kalimat tersebut dalam dirinya secara khusus sehingga mampu memberikan nilai yang dapat mengarahkan mereka kepada jalan yang lurus dan hasil yang memuaskan.Kekhususannya disebabkan ke-dalaman ikatan seorang hamba dengan Allah Swt. Kedekatan tersebut hadir dari ikatan yang terjalin antara keduanya. Ikatan yang terjalin antara seorang hamba dengan Allah Swt., telah melahirkan sebuah keyakinan dan keyakinan itu sendiri akan berkembang pesat saat memasuki pemahaman Iyyāka năbudū waiiyyā ka nastă̄n yang akan dibahas pada kajian di bawah.

Kalimat ayat bismillāhir-rahmānir-rahīm mampu mengarahkan seorang hamba kepada kejelasan sikap dan perbuatan yang bernilai di dalam mengarungi segala aktivitas kehidupan seorang hamba. Kalimat tersebut telah memberikan kejelasan baginya di dalam melaksanakan tugas kesehariannya di dunia adalah untuk Allah Swt. Pelaksanaan tugas yang diniatkan hanya kepada-Nya, telah mengantarkan seorang hamba untuk siap menerima kenyataan yang ada dihadapannya baik yang manis maupun yang pahit. Kenyataan tersebut ditemani oleh keberadaan Allah Swt., sebagai Tuhannya yang Mahapengasih lagi Mahapenyayang yang diberadakan oleh seorang hamba pada setiap kegiatannya tanpa ada yang lain selain Dia.

Seorang hamba akan menyeleksi apa yang dilakukannya apakah memiliki keterkaitan dengan apa yang dianjurkan oleh Allah Swt. Apabila apa-apa yang dilakukannya memiliki keterkaitan maka didudukkannya dengan kecintaan seorang hamba kepada Allah Swt., dan apabila tidak memiliki keterkaitan maka ia akan berhenti atau tidak melakukannya. Adapun masalah menerima kenyataan setiap yang dilakukan oleh seorang hamba dengan bismillähir-rahmānir-rahīm adalah karena niat yang dituju dalam setiap pelaksanaan kegiatannya hanya kepada dan untuk Allah Swt., sehingga hasil yang manis tetap dihadapi dengan pemujiaan kepada-Nya semata dan yang pahit pun turut dikalahkan dengn pujian itu sendiri, sehingga tidak memberikan dampak negative bagi seorang hamba.

Hal di atas yang akan dipahami oleh seorang hamba sebagai upaya perwujudan keyakinannya kepada Allah Swt., di dalam mengerjakan segala aktivitas kehidupannya.Kebenaran tersebut akan terlihat nyata saat seorang hamba menerima hasil dari pekerjaannya yang dilakukan dengan bismillāhir-rahmānir-rahīm, sehingga keluar kata pujian dari mulut seorang hamba yang ditujukan kepada Allah Swt. Kata pujian tersebut menjadi hakikat dari kebenaran itu yang menjelaskan kepada praktek seorang hamba bahwa saat ia bahagia ia senantiasa bersyukur dan tidak sombong dan di saat derita ia tahu bersabar serta tidak berputus asa. Nilai tasawuf dalam kandungan 
bismillāhir-rahmānir-rahīmakan hadir dalam diri seorang hamba dari pemahaman makna alhamdulillāhi-rabbil-ālamīn yang dimiliki seorang hamba setelah melewati pemahaman ayat bismillāhir-rahmānir-rahìm.

Intinya kalimat bismillāhir-rahmanir-rahìm adalah suatu kalimat yang dapat menghubungkan seorang hamba dengan Allah Swt., di dalam melakukan segala hal melalui niat yang hanya karena Allah Swt. Banyak perjalanan yang dikerjakan seorang hamba dan segala harapan tujuan yang diinginkan hanya bergantung hanya karena Allah Swt. Niat tersebut akan memelihara langkah hamba dalam melakukan perkataan dan perbuatan. Dengan niat tersebut, mampu memproteksi segala permasalahan yang muncul disebabkan keyakinannnya dalam melakukan segala hal. Semuanya merupakan bukti akan cinta seorang hamba hanya kepada Allah Swt. Apapun, dan bagaimanapun bentuk permasalahan yang dihadapi seorang hamba, ia akan selalu menghadapinya dengan penuh pengorbanan. Cinta butuh pengorbanan, dan pengorbanan adalah rasa nikmat dalam bercinta. Dengan nama Allah Swt., yang memiliki sifat Pengasih dan Penyayang akan menghilangkan segala rasa yang menghambat seorang hamba di dalam berbuat. Rasa tersebut merupakan sesuatu yang dicita-citakan seorang hamba sebagaimana seorang pekerja keras yang tidak memperdulikan kesusahannya karena gaji yang menjadi tujuan utamanya dan kenyataan tersebut sebagai bukti rasa kenikmatannya dalam bekerja.Banyak di antara para pekerja yang selalu berkata "Saya siap untuk menerima berbagai tantangan demi kenikmatan diakhirnya."

Bismillāhir-rahmānir-rahīm adalah bagian utama seorang hamba dalam melangkahkan niatnya di dalam melakukan segala perbuatan. Niat tersebut akan membuat segala perbuatannya terasa indah meskipun tidak indah dalam pandangan lahiriah. Niat tersebut juga menjadi kemudahan bagi seorang hamba dalam mengerjakan sesuatu, yaitu perbuatan yang terlihat mudah dan susah dalam kacamata lahiriah akan terlihat sama dan mudah dan nikmat dalam mengerjakannya. Kajian di atas memberikan pemahaman bahwa terdapat nilai tasawuf dalam ayat bismillāhirrahmānir-rahìm, yaitu niat yang lurus dan akan memperoleh tujuan yang lurus.

\section{Alhamdulillāhi-rabbil-'ālamīn}

Segala puji dan syukur kepada Allah Swt., adalah bagian lanjutan kenikmatan hamba tersebut di dalam memahami makna dari penyikapan bismillāhir-rahmānir-rahīm. Keberhasilannya dalam menghadapi segala permasalahan dengan persenjataan hanya karena (nama) Allah Swt., dan sifat-Nya yang Pengasih ${ }^{24}$ dan Penyayang ${ }^{25}$ dalam perlakuan seorang hamba dalam

\footnotetext{
${ }^{24}$ Mahapemberi yang tidak ada henti dan tidak memandang siapapun yang meminta pasti akan dberikan oleh Allah Swt. Sifat Ar-Rahmān Allah dapat menentukan pilihan-Nya terhadap seorang hamba bahwa mana yang berterima kasih walaupun tidak menyembah-Nya, namun sebagai pemberian jalan agar mereka akhirnya berpikir dan akhirnya untuk menyembah-Nya dan bagi yang menyembahNya (mengakui kebesaran-Nya dan mana yang tidak sama sekali mengingat akan kebesaran-Nya dan tidak berterimakasih kepada-Nya tetapi berterimakasih dan menyembah kepada selain diri-Nya.

${ }^{25}$ Rasa terimakasih atas pemberian telah menempatkan seorang hamba untuk dan hanya menyembah-Nya dan berterimakasih hanya kepada-Nya. Dengan rasa terimakasih seorang hamba maka
} 
melakukan segala perbuatan akan menjadi mudah untuk dihadapinya. Telah terlihat lebih jelas bahwa Allah Swt., adalah Pemelihara semesta alam. ${ }^{26}$

Tanthawi Jauhary mengatakan, "Pujian menurut ukuran ilmu orang yang memuji". Apakah orang yang memuji itu tahu betul akan sifat-sifat orang yang dipujinya barulah dia orang yang benar atas pujiannya. Kebalikannya, manakala dia memuji kepada seseorang, padahal kurang pengetahuannya terhadap orang itu, niscaya pujiannya itu lebih hampir pada kedustaan.Oleh karena itu Tanthawi Jauhari telah memberi konklusi dalam Tafsirnya "Orang Islam belum dapat memuji Allah dengan sebenar-benarnya selama mereka belum mengetahui perat uran-peraturan ${ }^{27}$ Thabi 'at (Nature) dan sekalian keajaiban perbuatan Allah."Ia melanjutkan perkataannya, "Manakala ummat Islam bermaksud hendak memuji Allah dengan sebenar-benarnya maka hendaklah lebih dahulu mereka mempelajari sekalian peraturan dan kehalusan kejadian makhluk. Sehingga tidak ada satu ilmu yang tidak dibaca dan dipahamkan barulah ketika itu mereka dapat memuji Allah dengan sebenar-benarnya pujian. Sebagaimana ummat-umat memuji-memuji pemukanya, sesudah mereka tahu jasa dan keberanian pemuka-pemukanya itu yang mana mereka itu mendapat manfaat dari padanya." ${ }^{28}$

Abu Ja'far bin Jarir mengatakan: "Alhamdulillāh berarti syukur kepada Allah Swt., semata dan bukan kepada sesembahan selain-Nya, bukan juga kepada makhluk yang telah diciptakan-Nya, atas segala nikmat yang telah Dia anugerahkan kepada hamba-hamba-Nya yang tidak terhingga jumlahnya, dan tidak ada seorangpun selain Dia yang mengetahui jumlahnya. Berupa kemudahan berbagai sarana untuk mentaati-Nya dan anugerah kekuatan fisik agar dapat menunaikan kewajiban-kewajiban-Nya. Selain itu, pemberian rizki kepada mereka di dunia, serta pelimpahan berbagai nikmat dalam kehidupan, yang sama sekali mereka tidak memiliki hak atas hal itu, juga sebagai peringatan dan seruan kepada mereka akan sebab-sebab yang dapat membawa kepada kelanggengan hidup di

akan memperoleh kasihsayang Allah. Seorang hamba akan sadar bahwa segala pemberian datangnya dari Allah dan kepada-Nya seorang hamba agar menyembah dan berterimakasih atas pertolongan yang diberikan-Nya.

${ }^{26}$ Segala perlakuan Allah Swt baik itu cocok menurut hamba maupun tidak cocok menurut hamba adalah sesunguhnya perlakuan baik Allah buat hamba-Nya, karena tidak ada sesuatu pun yang Ia ciptakan yang sia-sia buat hamba dan makhluk-Nya. Rabbana Ma Khalaqta hādza Bātilan subhānaka faqinā 'adzābannār...(al-Imran [3]:191). Apapun yang tidak berkenan oleh hamba, semua itu disebabkan

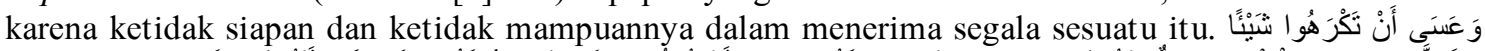

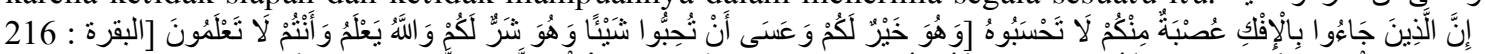

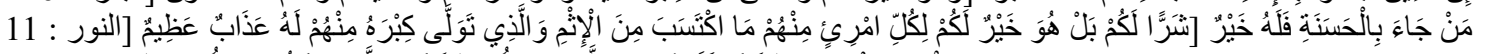

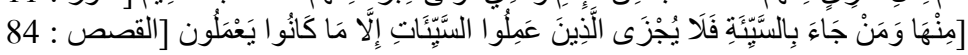

${ }^{27}$ Yaitu hanya menuhankan Allah Swt tidak menuhankan yang lainnya.Peraturan ini merupakan pesan utama yang disampaikan oleh Allah Swt kepada setiap Nabi Rasul agar memudahkan para hamba di dalam mengarungi bahtera kehidupannya di dunia. Peraturan ini terlihat jelas di beberapa Firman Allah Swt di antara dalam surat al-Nahl:36.

${ }^{28}$ H. A. Halim Hasan Daulay dkk, Tafsir Alquran..., h. 13-14 
surga tempat segala kenikmatan abadi. Hanya bagi Allah Swt., segala puji, baik di awal maupun di akhir. ${ }^{29}$

Pujian-pujian yang hanya ditujukan seorang hamba kepada Allah Swt., telah memberikan semangat di dalam melaksanakan setiap aktivitasnya dan memperoleh kebahagiaan karena senantiasa dihargai oleh Allah Swt.,akan setiap kegiatan tersebut. Kedua hal itu yang akan mengarahkan seorang hamba untuk memasuki jiwa yang ikhlas di dalam berbuat. Pemikiran dan pemahaman tersebut telah tertuang di dalam akal seorang hamba atas kelayakan Allah untuk dipuji dan dipuja karena hanya Dia yang memiliki pujian tertinggi dari pada apa-apa yang telah diberikan seorang hamba akan pujian yang ada kepada selain Allah Swt.

Sebagaimana telah diterangkan Rabbidengan makna tarbiyah (memelihara). Tarbiyah Allah Swt diri pada manusia ada terbagi dua. Pertama, tarbiyah tentang kejadiannya, agar sempurna akalnya.Kedua, tarbiyah syara yang diwahyukan-Nya kepada tiap-tiap orang dengan perantara Rasul-rasul agar sempurna kejadian mereka dengan ilmu dan amalnya. Oleh karena itu, tidak ada yang lain selain Allah Swt., yang mengatur jalan ibadah bagi manusia, dan tidak boleh seorang pun juga mengharamkan atau menghalalkan sesuatu selain dari pada Allah Swt. ${ }^{30}$ Hal di atas merupakan pedoman jatuhnya sebutan pujian yang diberikan seorang hamba kepada makhluk agar merujukkan pemberian pujian tersebut hanya kepada Allah Swt.

Dari kesimpulan di atas dapat dinyatakan bahwa tidak sah ucapan Alhamdulillāh seorang hamba bila tidak memahami arti kebahagiaan yang untuk bersyukur dan menyikapi arti penderitaan yang untuk bersabar sebab, ia belum mengenal makna kebesaran Allah Swt. Seorang hamba dapat sah dalam mengucapkan alhamdulillāhi-rabbil-'ālamīnbila ia telah menempatkan dirnya hanya bersama Allah Swt., sehingga ia akan mampu bersyukur dan tidak sombong atas kebahagiaan dunia yang diberikan-Nya dan mampu bersabar dan tidak berputus asa atas penderitaan dunia yang singgah dalam kehidupannya.

Mengembangkan kajian di atas penulis menambahkan bahwa alhamdulillāh adalah kajian terdalam setelah bismilläh..Alhamdulillah merupakan sebuah pernyataan dari Allah Swt., yang menganjurkan kita untuk senantiasa hanya memuji kepada-Nya.Ia adalah Sosok yang tertinggi dan memiliki tempat untuk dipuji oleh seorang hamba. Pujian seorang hamba yang dilakukan kepada siapapun, apapun dan kondisi bagaimanapun adalah pujian yang tidak terlepas dari karena memuji Allah Swt. Keutamaan dalam memuji-Nya adalah menempatkan seorang hamba untuk siap menerima apapun model pemberian yang diberikan oleh Allah Swt., kepadanya, baik kekayaan atau kemiskinan, kecantikan atau kejelekan rupa dan badan yang tinggi atau pendek. Bagi seorang hamba tetap akan menerima

\footnotetext{
${ }^{29}$ Lihat, 'Abdullah bin Muhammad bin 'Abdurrahman bin Ishaq Alu Syaikh (Pentahqiq/Peneliti), O Tafsir Ibn..., h. 24.

${ }^{30}$ Lihat, H. A. Halim Hasan Daulay dkk, Tafsir Alquran..., h. 44.
} 
dengan legowo atas segala pemberian Allah Swt., karena seorang hamba, hanya mewujudkan pemujian atas pemberian-Nya.

Bila pujian telah dijadikan oleh seorang hamba sebagai barometer penerimaannya atas pemberian Allah Swt., maka ia akan menyikapi segala pemberian yang berupa bentuk indah secara lahiriah dengan selalu bersyukur kepada-Nya. Rasa syukur tersebut akan melahirkan jiwa yang tidak sombong kepada Allah Swt dan kepada makhluk-makhluk lainnya. Dengan pujian-pujian yang dikedepankan seorang hamba kepada-Nya dalam setiap menerima pemberianNya yang berupa sesuatu yang tidak indah secara lahiriah akan disikapi dengan rasa bersabar. Rasa sabar tersebut akan melahirkan jiwa seorang hamba yang tidak berputus-asa. Seorang hamba yang mampu mengendalikan atau memulangkan segala pemberian berupa sesuatu yang indah dan tidak indah tersebut kepada Allah Swt., dan hamba akan memperoleh kenikmatan yang nyata dalam kehidupan di dunia dan di akhiratnya. Pernyataan di atas penulis sebut dengan istilah "jalan kepastian menuju kenikmatan dalam kehidupan dan wujud dari bentuk kebenaran di dunia dari Sang Penguasa Allah Swt dan yang Maharahmān”. Suatu jalan yang pasti dan yang mampu membuat seorang hamba untuk mampu dalam mengendalikan diri di saat bahagia untuk tahu bersyukur dan tidak sombong dan jalan yang mampu membuat seorang hamba untuk bersabar di saat derita dan tidak berputus-asa, karena yang dituhankannya dan diagungkan olehnya hanya Allah Swt., dan tidak ada yang lain bersama seorang hamba kecuali Ia.

Jalan kepastian menuju kenikmatan tersebut terinspirasi dari dua hal. Pertama, kegagalan Socrates dalam mencari kebahagiaan secara universal, seperti larangan bagi orang yang berbuat jahat di mata agama dan telah menghadang kebebasannya untuk berbuat jahat dan dia tidak bahagia. Kedua, pernyataan Rasulullah dalam sebuah hadis yang kesimpulannya, tidak akan diterima rasa ucapan syukur seorang hamba (sebagai wujud rasa kebahagiaan seorang hamba atas pemberian Allah) kepada Allah Swt bila tidak diawalinya di dalam rasa syukur tersebut dengan memuji Allah Swt.

\section{Arrahmānir-rahīm}

Kalimat di atas menjelaskan dua sifat Agung Allah Swt., yaitu, alRahmānyang berupa sifat Allah Swt., yang memberikan sesuatu kepada setiap hamba dan makhluk-Nya dan al-Rahīm yang berupa sifat kasih sayang Allah Swt., yang hanya diberikan-Nya kepada orang yang mengakui akan kebesaran dan menyembah-Nya. Al-Rahmān al-Rahìm juga merupakan pernyataan seorang hamba akan bukti kasih sayang Allah Swt., yang murah memberikan sesuatu kepada setiap makhluk-Nya tanpa membedakan mereka dan mengasihi hambahamba-Nya yang memahami wujud ketuhanan Allah Swt. Hanya orang-orang yang tidak paham tentang wujud kasihsayang Allah Swt., yang akan memiliki 
kegelisahan di dalam hidupnya dengan penuh penderitaan baik di kala memiliki fasilitas dunia ataupun tidak.

Rahmānullah yang tertinggi bagi segenap makhluk adalah nafas atau kehidupan yang diberikan-Nya. Dengan kehidupan tersebut akan menjadi berharga segala fasilitas yang diberikan-Nya. Itupun bila digunakan dengan tetap merujuk kepada nilai tasawuf ayat pertama dan kedua dari surat al-Fatihah. Rahmānullah menjadi tidak berharga bila segala fasilitas yang diberikan-Nya kepada makhlukmakhluk-Nya tidak dikaitkan dengan rahīmullah, yaitu Sayang-Nya Allah Swt., kepada makhluk-makhluk-Nya yang menyadari atas pemberian-Nya (Rahmānullah) dan berkembang kepada rahīmullah. Bukankah semua yang ada memiliki keterikatan dan berjalan secara sistematis seperti keberadaan akibat karena keberadaan sebab atau bahasa lainnya ada sebab pasti ada akibatnya.Untuk dapat terwujud semua hal di atas Allah Swt., telah memberikan perhatian-Nya dengan penciptaan dan Pemeliharaan atau yang dikenal dengan tarbiyyah, yaitu sebuah kata yang menjelaskan kedudukan rabulālamīn.Agar terlestarikan kedudukan Penciptaan dan Pemeliharaan maka diperlukan pendidikan dari Allah Swt. Untuk mensukseskan hakikat pendidikan tersebut maka diadakan ganjaran bagi makhluk khususnya para hamba Allah Swt.

Tanthawi Jauhary telah menyebutkan, bahwa, tarbiyah (pendidikan) berkehendak pada dua pekerjaan, yakni rahmat dan kekerasan.Apakah tidak didapati keduanya bersama-sama, itulah yang dinamakan tarbiyah yang pincang.Allah telah menjadikan ibu-ibu lebih banyak hampir pada sifat rahmat, sedang bapak-bapak lebih dekat kepada kekerasan atau tepatnya ketegasan. Dari itu, manakala salah seorang diantara keduanya dalam keadaan lupa, maka alamat akanterjadi kerusakanakan tarbiyah anak-anak. Oleh karena, itu, Allah Ta'ala mengisyaratkan dengan firman-Nya "Ia mendidik dan memelihara Alam ini dengan sifat ar-Rahman dan ar-Rahim." ${ }^{1}$

Muhammad Abduh mengatakan dalam Tafsir al-Mannarnya, "Sungguhpun Allah sudah mengadakan berbagai-bagai hukuman di dalam dunia dan menyediakan berbagai-bagai azab di akhirat untuk orang yang melewati batasbatas-Nya dan orang yang melanggar larangan-larangan-Nya, sekalian itu tidak ada menafikan keumuman rahmat Tuhan bagi seluruh hamban-Nya.Karena walaupun hukuman itu pada lahirnya sebagai pembalasan, tetapi pada hakikatnya rahmat.Disinilah terletaknya tarbiyah yang diberikan Tuhan pada manusia, sebagaimana tarbiyah telah melarang orang agar jangan terjerumus kepada pekerjaan-pekerjaan yang melanggar batas-batas yang sudah ditentukan Syari'at Tuhan.Adapun berpaling dari pada Syari'at itu membawa pada kecelakaan dan bala yang besar.Sebaliknya, saat seseorang berdiri tetap dalam batas Syari'at itu, perbuatannya itu pulalah membawanya pada kebahagiaan dan kenikmatan. ${ }^{32}$

\footnotetext{
${ }^{31}$ Lihat, Ibid.,h. 45.

${ }^{32}$ Lihat, Ibid.,
} 
Sifat al-Rahmān dan al-Rahìm Allah Swt., yang telah mengejewantah dalam tubuh hamba-Nya dan telah mampu membuat hamba-Nya agar kuat dalam menghadapi kenyataan. Seorang hamba yang melihat teman lainnya dalam keadaan berbuat salah dan menegurnya serta tidak memperdulikan bahwa temannya tidak mau ditegur atas kesalahan yang dilakukannya adalah bagian dari kasihsayang Allah tersebut. Teguran yang dilakukan seorang teman tadi merupakan pemberian yang ia berikan kepada siapapun, yaitu memberikan hal yang baik kepada orang yang baik maupun kepada orang yang lagi berbuat tidak baik. Sesungguhnya sifat tersebut adalah sifat yang berpandangan luas, sehingga ia berharap dengan pemberiannya berupa nasehat mampu menciptakan kasih sayang yang berupa kesadaran bagi orang yang berbuat salah. Perubahan pada seseorang teman tersebut kepada hal yang baik telah menempatkan diri sipenegur sebagai manusia yang terbaik, yaitu manusia yang bermanfaat bagi manusia lainnya tanpa mengenal siapapun manusia yang akan ditegur untuk diperbaikinya

Ar-rahman ar-Rahim merupakan dua nomina yang berasal dari kata ArRahmah dan ditujukan untuk menunjukkan makna "sangat".Ar-Rahmah lebih tegas dari pada ar-Rahim.Ar-Rahman merupakan nomina berrefleksi.Hal ini berbeda dengan orang yang memandangnya dan menduganya sebagai nomina tidak berrefleksi. Alasan bagi pandangan ini ialah keterangan yang dimunculkan oleh Tirmidzi dan disahihkannya, dari Abdurrahman bin Auf ra., bahwa dia mendengar Rasulullah saw., bersabda, "Allah Ta'ala berfirman, 'Aku adalah ar-Rahman. Aku telah menciptakan rahim (kandungan) dan Aku ambil dari Nama-Ku menjadi namanya. Barangsiapa yang menyambungkannya, maka Akupun menyambungkannya. Dan barangsiapa yang memutuskannya, maka Aku pun akan memutuskannya."(HR. Tirmidzi). ${ }^{33}$

Al-Rahmah merupakan gabungan dari al-Rahmān dan al-Rahīm Allah Swt., artinya dua nama agung Allah tersebut tidak dapat terpisahkan dan memiliki sistematika kajian yang harus diterapkan pada diri seorang makhluk khususnya hamba Allah Swt. Kasih dan sayang Allah Swt tersebut merupakan alat utama bagi seorang hamba di dalam memahami Cinta-Nya dan berupaya untuk dimiliki oleh setiap hamba-Nya. Hal ini merupakan kata kunci utama tujuan para sufi dan pecinta Allah dalam memperoleh Cinta-Nya. Dengan keberadaan al-Rahmān dan al-Rahìm Allah Swt., maka seorang hamba akan tersugesti dalam menjalani segala aktivitas kehidupannya dengan kebahagiaan sempurna. Meskipun kesempurnaan itu hanya milik Allah, namun telah dirasakan oleh para hamba-Nya akan kesempurnaan tersebut. Bahasa lainnya berbuyi "ada dan tiadanya fasilitas dunia itu tetap akan selalu ada kebahagiaan bagiku dengan kasih sayang-Mu wahai Allah Swt yang datang berupa bahtera Cinta-Mu dan adanya fasilitas dunia padaku, semua tidak ada artinya bila tanpa kasih sayang-Mu yang berwujud berupa Cinta60.

${ }^{33}$ Muhammad Nasib ar-Rifa'i, Ringkasan Tafsir Ibnu Katsir, (Jakarta:Gema Insani, 1999), h. 59- 
Mu kepadaku". Perasaaan di atas merupakan nilai tasawuf yang senantiasa dinanti-nantikan oleh para pecinta Allah Swt.

Oleh karena itu, nilai tasawuf dari ayat di atas berupa penegasan dari Allah Swt bagi para hamba untuk selalu ingat bahwa memberadakan kasih sayang-Nya mampu menjadikan semua fasilitas dunia terlihat hal yang biasa, sehingga mampu dilewati dengan kemudahan dan mendorongnya untuk memperoleh yang lebih besar yaitu Cinta Allah Swt. Kajian tersebut akan menjelaskan bahwa Allah Swt., yang memiliki langit dan bumi beserta isinya dan kelayakan-Nya dalam menempati diri-Nya sebagai Raja di hati orang-orang yang mencari ketidak kacauan atau kebahagiaan.

\section{Mālikiyaumid-dīn}

Pengkhususan kerajaan pada hari pembalasan tersebut tidak menafikan kekuasaan Allah atas kerajaan yang lainnya (dunia), karena telah disampaikan sebelumnya bahwa Dia adalah Rabb semesta alam.Kekuasaan-Nya itu bersifat umum di dunia maupun di akhirat. Adanya tambahan kalimat yang artinya hari pembalasan, karena pada hari itu tidak ada seorang pun yang dapat mengakungaku akan sesuatu dan tidak juga dapat berbicara kecuali dengan seizin-Nya. Sebagaimana firman Allah dalam surat an-Naba:38 yang artinya "pada hari itu ketika ruh dan para Malaikat berdiri bershaf-shaf, mereka tidak berkata-kata kecuali siapa yang telah diberi izin kepadanya oleh Rabb yang Mahapemurah, dan ia mengucapkan kata yang benar." Hari pembalasan berarti hari perhitungan bagi semua makhluk, disebut juga hari kiamat.Mereka diberi balasan sesuai dengan amalnya.Jika amalnya baik, maka balasannya pun baik.Jika amalnya buruk, maka balasannya pun buruk kecuali bagi orang yang diampuni. ${ }^{34}$

Secara kontekstual ayat tersebut dapat dipahami sebagai keterangan sempurna dari ayat sebelumnya, yaitu menerangkan bahwa dengan kasihsayang Allah Swt., yang diberikan kepada hamba-hamba-Nya dan dipahami dengan sebaik-baiknya mampu menyikapi rasa bahagia dengan bersyukur dan rasa derita dengan bersabar, telah membuktikan bahwa Allah Swt., adalah Raja di hari pembalasan. Dalam bahasa pecinta Allah Swt.,yaitu memahami Mālikiyaumid-dīn adalah Raja yang memberikan ganjaran kepada para hamba khususnya dan makhluk-Nya pada umumnya yang telah menyikapi rasa kasihsayang-Nya secara positif atau negative. Bagi orang yang memperoleh Cinta Allah Swt., akan menyadari dengan sejati bahwa Allah Swt., yang telah memiliki wewenang dalam pemutusan akan setiap perbuatan yang dilakukan hamba selama di dunia, sehingga memberikan rasa yang besar untuk memperoleh rahmat-Nya. Tidak akan ada satupun yang mampu memiliki rasa tersebut dan mampu memberikan kenyamanan akan rasa tersebut kepada siapapun kecuali dari-Nya.

\footnotetext{
${ }^{34}$ Lihat, 'Abdullah bin Muhammad bin 'Abdurrahman bin Ishaq Alu Syaikh (Pentahqiq/Peneliti), Tafsir Ibn..., h. 27
} 
Keberhasilan Allah Swt., yang telah terlihat pada diri seorang hamba di dalam ayat di atas, yaitu, keberhasilan-Nya dari sisi sebagai Pemilik maupun sebagai Raja. Dapat dipastikan bahwa Allah Ta'ala yang memiliki sekalian makhluk dan akan membalas mereka baik di dunia maupun di akhirat dengan pahala kepada orang yang taat dan rajin beramal baik. Menyiksa dan menghinakan siapa pun yang pemalas dan durhaka.Pernyataan ini juga ditegaskan oleh Thanthawy dengan istilah sempurnalah tarbiyah dan peraturan alam yang dilakukan Allah Swt. ${ }^{35}$

Dua hal yang dihadirkan tasawuf berupa nilai yan terdapat dalam surat alFatihah, pertama, bahwa Allah Swt adalah pencipta, pemilik dan pemelihara akan alam semesta beserta isinya, sehingga pernyataan tersebut telah memberikan kesadaran seorang hamba agar ia menjalani segala aktivitas kehidupannya di dunia dan menuntaskannya karena Allah Swt semata. Kedua, Allah Swt adalah penentu dan pemutus segala ketentuan dan keputusan yang dilakoni oleh seoang hambaNya. Ketentuan dan keputusan tersebut tidak lepas dari kemaslahatan bagi hamba tersebut, artinya keuntungan yang diberikan kepada hamba bila mengerjakankeputusan dan kerugian baginya bila meninggalkannya dan bukan keuntungan juga kerugian bagi Allah Swt., bila kita mengerjakan dan meninggalkan keputusan-Nya Pemahaman akan kedua hal tersebut yang telah memberikan kesadaran kepada seorang hamba untuk melakukan segala aktivitas kehidupannya karena Allah Swt., semata dan untuk meraih cinta-Nya serta mencapai kedekatan kepada-Nya. Cinta dan kedekatan seorang hamba kepada Allah Swt.,akan menghapuskan kenikmatan yang sesaat dari kebahagiaan dan siksa dari penderitaan lahiriyah. Ayat tersebut akan memicu seorang hamba untuk memasuki diri kepada pernyataan berikutnya dari firman Allah Swt., yaitu Iyyāka na'budu wa iyyāka nasta'īn. Ayat tersebut akan mengantarkan seorang hamba kepada deklarasi sejati atau wujud kepasrahan diri dan ketergantungan abadi kepada Allah yang Mahasuci.

\section{Iyyā ka-na'budu wa iyyā ka-nasta'̄n}

Ayat di atas merupakan inti dari kata hati seorang pecinta sejati atau seorang hamba yang ingin mendapatkan cinta Allah Swt. Ayat yang telah membangun kehidupan yang sesungguhnya bagi seorang hamba dalam mengarungi bahtera kehidupan di dunia. Penyembahan seorang hamba kepada Allah Swt., akan menjadi pegangan utama baginya di dalam mengiringi setiap langkah dalam beraktivitas di dunia, sedangkan pertolongan Allah Swt., yang diharapkannya akan menjadi kesadaran nyata bahwa ia bukan siapa-siapa, namun ia adalah sebagai seorang yang perlu dipelihara dan diarahkan setiap geraknya dalam menghadapi kehidupan di dunia yang banyak memiliki keterpesoanaan sementara. Dunia merupakan pancaran keagungan Allah Swt., namun dunia tidak mampu

\footnotetext{
${ }^{35}$ Lihat, H. A. Halim Hasan dkk, Tafsir Alquran..., h. 47.
} 
mengarahkan bimbingan kejalan Allah Swt., kecuali atas izin-Nya, karena dunia akan menjadi senjata utama syaitan di dalam menjerumuskan seorang hamba kepada kesesatan dan kedurhakaan kepada Allah Maharahman.

Manakala seorang hamba telah berpegang kepada pegangan utamanya, yaitu hanya menghambakan diri kepada Allah Swt., maka seluruh ciptaan dunia dan alam semesta beserta isinya yang merupakan pancaran dari keagungan Allah Swt., yang akan diperintahkan-Nya untuk mengiringi langkah seorang hamba yang berpegang pada pegangan utama tersebut dan keselamatan yang akan hadir dalam kehidupan di dunia. Keselamatan yang diperolehnya merupakan wujud pertolongan Allah Swt., dari permohonan yang dimintanya.

Berkata sebagian salaf bahwa al-Fatihah adalah rahasia Alquran, dan rahasianya terletak pada kalimat iyyā ka na'budu wa iyyāka nasta'īn. lafaz tersebut telah menuntun kepada pelepasan diri seorang hamba terhadap kesyirikan dan berserah diri kepada Allah Swt. Iyyāka merupakan objek yang didahulukan untuk objek pembatasan, supaya tujuan pembicaraan yang terpokus kepada apa yang hendak diutarakan, yaitu "hanya kepada Engkau ya Allah" kami menyembah yang maksudnya seorang hamba tidak beribadah kecuali hanya kepada Allah Swt., dan tidak berserah diri seorang hamba hanya kepada-Nya. Hal tersebut merupakan bagian dari kesempurnaan dari ketaatan seorang hamba kepada Allah Swt. Secara bahasa, ibadah berarti ketundukan.Secara istilah ibadah adalah suatu hal yang menyatukan kesempurnaan kecintaan, ketundukan, dan ketakutan. Sebagian ulama salaf mengatakan bahwa al-Fatihah merupakan rahasia Alquran yang terletak pada ayat “iyyāka na'budu wa iyyāka nasta'̄n" penggalan kalimat pertama yaitu iyyaaka na'budu merupakan bagian dari penyucian dari kemusyrikan. Dan yang kedua, yaitu iyyāka nasta`̄n merupakan upaya penyucian dari upaya, usaha, dan kekuatan yang menyerahkan segalanya kepada Allah yang Mahamulia lagi Mahaagung. ${ }^{36}$

Dua kalimat dari ayat tersebut telah meberikan keteguhan kepada seorang hamba untuk dapat konsisten dalam berbuat dan konsenstrasi dalam menghadapi segala bentuk kehidupan tanpa ada gangguan dan godaan.Kemampuan seorang hamba dalam menyikapi segala godaan dan gangguan di muka bumi dengan konsentrasi dan konsistensi yang tinggi telah dapat menempatkan dirinya sebagai seorang yang berhasil dalam menyembah Allah yang Mahasuci. Segala perbuatan yang dilakukan selalu diawali dengan permohonan bimbingan dengan bahasa bergantung hanya kepada Allah Swt., dan dilakukan dengan bahasa penyerahan diri secara maksimal hanya kepada Allah Swt., dan tidak kepada siapapun.

Melalui pernyataan Ibn Qayyim al-Jauziyyah ${ }^{37}$, di dalam menafsirkan iyyāka-nabudu sesungguhnya tidakakan menyembah seorang hamba pada

\footnotetext{
${ }^{36}$ Muhammad Nasib ar-Rifa'i, Ringkasan Tafsir..., h. 62. Lihat juga, 'Abdullah bin Muhammad bin 'Abdurrahman bin Ishaq Alu Syaikh (Pentahqiq/Peneliti), Tafsir Ibn..., h. 29

${ }^{37}$ Lihat, ibn Qayyim Al-Jauziyyah, Tahdzibu Madariju as-Salikin,Hadzbahu; Abd al-Munim Shalih al-Ali a-Izzy, jld. I, (Beirut Libanaon; Muassastu ar-Risalah, 2000), h. 30
} 
Tuhannya Pemelihara semesta alam yang Mahatinggi kecuali sesembahan yang dilakukan dalam beribadah dengan kecintaan kepada Allah Swt., dan keridhaanNya. Dalam beribadah kepada-Nya adalah ibadah seorang hamba yang melakukannya dengan rasa syukur, cinta dan takut kepada-Nya dengan naluriah, diterima oleh akal yang selamat.Akan tetapi metode yang dilakukan dalam beribadah atau menyembah kepada Allah Swt., adalah tidak ada sesembahan apapun kecuali menyembah-Nya.Tidak ada jalan untuk mengetahui-Nya kecuali dengan jalan yang disampaikan oleh Rasul-Nya dan penjelasan-penjelasan tentang semua di atas (syukur, cinta dan takut kepada Allah).

Ibadah merupakan kedudukan yang sangat agung, yang dengannya seorang hamba menjadi mulia, karena kecondongannya kepada Allah Ta'ala saja, dan Dia telah menyebutkan Rasul-Nya Saw., sebagai hamba-Nya yang menempati kedudukan yang paling mulia. ${ }^{38}$ Ibadah menurut hemat penulis adalah bukti dari kecintaan seorang hamba kepada Allah Swt, sehingga ia akan melakukan segala bentuk ibadah hanya karena-Nya dan menghasilkan nilai yang berkualitas dalam kehidupannya. Ibadah dalam harapan bertasawuf merupakan keutuhan perbuatan seorang hamba yang ingin menggapai cinta Allah Swt., sehingga tidak akan ada keraguan dan hasil yang tidak berkualitas yang dilahirkan, sebab ibadah yang dikerjakan sebagai bukti cinta seorang hamba kepada Allah yang Maharahman.

Ibn Qayyim al-Jauziyyah menjelaskan keutamaan-keutamaan ayat yang berbunyi iyyā ka-nabudu wa iyyāka-nastā̄n adalah sebagai obat bagi dua penyakit yang berbahaya bagi seorang hamba, yaitu penyakit ria dan penyakit sombong. Penyakit ria disembuhkan dengan kalimat iyyāka-nabudu dan penyakit sombong disembuhkan dengan kalimat iyyā ka-nastā̄n.

Ria adalah penuhan diri seorang hamba terhadap dirinya bukan kepada Allah Swt. Meskipun secara lahiriah ia menyembah Allah Swt., namun hakikatnya ia hanya menyembah dirinya saja. Dengan pengukuhan keberadaan Allah Swt., di hati seorang hamba akan mensucikan dirinya dari penuhan-penuhan seorang hamba kepada selain Allah Swt. Setiap perbuatan seorang hamba akan terlaksana karena Allah Swt., bukan karena diri hamba tersebut. Adapun sombong adalah perasaan seorang hamba dalam menyatakan dirinya sebagai penolong bagi orang lain dan hanya pada dirinya orang-orang akan memohon pertolongan. Seorang hamba yang merasa tersebut telah lupa bahwa ia mampu memberikan pertolongan karena diizinkan Allah Swt., atau ditolong-Nya. Dengan pengukuhan pertolongan Allah Swt., senantiasa menyertai rasa pertolongan seorang hamba kepada orang lain dan akan mensucikan rasa sombong yang ada pada dirinya.

\footnotetext{
${ }^{38}$ Lihat, 'Abdullah bin Muhammad bin 'Abdurrahman bin Ishaq Alu Syaikh (Pentahqiq/Peneliti), Tafsir Ibn..., h. 31
} 


\section{Ihdinașșirātol mustaqīm}

Setelah memperoleh petunjuk bahwa hanya kepada Allah Swt., seorang hamba dalam menyembah dan hanya kepada Allah Swt., dan memohon pertolongan, telah menjadi harapan untuk senantiasa diberikan petunjuk yang hakiki, karena tidak ada tempat untuk meminta petunjuk selain kepada diri-Nya.

Kata dan makna hidayah dalam ayat di atas adalah pengertian bimbingan dan petunjuk. Sebagaimana firman Allah Swt., di dalam surat al-Syura ayat 52 yang artinya" Dan sesungguhnya engkau (Rasulullah Saw.,) benar-benar memberi petunjuk kepada jalan yang lurus." Seorang hamba senantiasa membutuhkan Allah Swt., dalam setiap saat dan setiap situasi agar diberikan keteguhan, kemantapan, penambahan, dan kelangsungan hidayah, karena ia tidak kuasa memberikan manfaat atau mudharat kepada dirinya sendiri kecuali dari Allah Swt., yang menghendaki. Oleh karena itu, Allah Swt., selalu membimbingnya agar ia senantiasa memohon kepada-Nya setiap saat dan supaya Dia memberikan pertolongan, keteguhan, dan taufik. Orang yang berbahagia adalah seorang hamba yang diberi taufik oleh Allah Swt., untuk senantiasa hanya memohon kepada-Nya, sebab Ia telah menjamin akan mengabulkan permohonan seorang hamba jika ia memohon kepada Allah Swt., apalagi permohonan orang yang dalam keadaan terdesak dan sangat membutuhkan bantuan-Nya pada tengah malam dan siang hari. ${ }^{39}$

Hidayah menurut Ibn Qayyim al-Jauziyyah adalah penjelasan, tuntunan, pembenaran dan ilham.Tidak ada jalan menuju penjelasan dan tuntunan Allah Swt., kecuali melalui arahan Rasul-Nya. Oleh karena itu,kemuncuan penjelasan, tuntunan dan pengenalan yang sistematis akan diri Allah Swt., akan mengarah kepada petunjuk dan pembenaran-Nya dan menjadikan keyakinan di hati dan melahirkan cinta mendalam seorang hamba kepada-Nya serta Ia mengisi hati seorang hamba dan menjadikan Allah Swt.,selalu ada di hati orang yang teridhoi dan selalu berada dalam kehendak-Nya. ${ }^{40}$

Ayat di atas merupakan ayat yang dinilai sebagai permohonan utama bagi seorang hamba agar ibadah yang dilakukan senantiasa setia mendampinginya yang tidak berkurang dan tidak surut setelah pegangan utama yang dimiliki seorang hamba (penghambaan diri hanya kepada Allah Swt semata). Harapan tersebut merupakan penghapusan kekhawatiran seorang hamba, yaitu khawatir akan perpisahan dirinya dari Allah Swt.

\section{Șirātololląìna-anamta- 'alaihim ghairil-maghdhũ bi- 'alaihim walādh-dhāllīn}

Ayat tersebut adalah inti dari permohonan yang diminta oleh seorang hamba yang mengandung dua arah permohonan.Pertama, permohonan untuk

\footnotetext{
${ }^{39}$ Lihat, Ibid., h. 33

${ }^{40}$ Lihat, ibn Qayyim Al-Jauziyyah, Tahdzibu Madariju as-Salikin,Hadzbahu; Abd al-Munim Shalih al-Ali a-Izzy, jld. I, (Beirut Libanaon; Muassastu ar-Risalah, 2000), h. 31
} 
ditunjukkan kepada jalan seperti orang-orang yang dianugerahkan oleh Allah Swt., akan sebuah nikmat, seperti Nabi Ayyub As., yang mampu menahan diri dari segala penderitaan berupa ujian, di antaranya penyakit yang berkepanjangan dari Allah Swt., dan kemampuan tersebut adalah bagian dari kenikmatan. Nabi Yusuf As., yang mampu menahan diri dari kesombongan atas kesehatan dan ketampanan dirinya untuk senantiasa selalu berterima kasih kepada Allah Swt., dan merupakan kenikmatan baginya. Nabi Sulaiman As., yang mampu menahan diri dari keangkuhan sebab kekayaannya dan kemampuan tersebut bagian dari kenikmatan. Nabi Isa As., yang mampu menahan diri dari penderitaan serba kekurangan akan hal-hal duniawi dan kemampuannya juga merupakan kenikmatan. Serta Nabi Muhammad Saw., yang memiliki empat pengalaman dari Nabi-nabi di atas dan kemampuannya merupakan anugerah yang paling besar dari Allah Swt. Kenikmatan di atas adalah kenikmatan yang diharapkan oleh seorang hamba. Kedua, permohonan untuk dapat dihindarkan dari orang-orang yang dimurkai oleh Allah Swt., seperti Fir'aun, yang sombong dengan kekuasaannya.Qorun, yang sombong dengan hartanya.Hamman yang angkuh dengan kepintarannya.Tsa'labah, yang miskin dan sombong setelah kekayaan menghampirinya.Dajjal yang menguasai empat sifat buruk di atas.

Ibn Qayyim al-Jauziyyah menerangkan tentang orang-orang yang dimurkai oleh Allah Swt., adalah orang-orang Yahudi yang diberi-Nya petunjuk. Petunjuk yang diterima oleh mereka tidak diterapkan dalam kehidupannya sehari-hari, sehingga menimbulkan kemurkaan dari Allah Swt. Adapun orang-orang yang dinyatakan sesat adalah orang-orang Nasrani yang menyatakan Nabi Isa As., (seorang pembawa berita dan utusan Allah Swt) sebagai anak Tuhan. Pernyataan tersebut telah menetapkan orang Nasrani sebagai orang-orang yang tersesat.

Ibn Katsir menjelaskan bahwa maksud ayat tersebut adalah permohonan seorang hamba untuk dapat jalan yang lurus yaitu jalan orang-orang yang telah diberikan Allah Swt., sebuah nikmat kepadanya, yaitu mereka yang memperoleh hidayah, istiqamah, dan ketaatan kepada Allah Swt., dan Rasul-Nya, serta mengerjakan perintah-Nya dan meninggalkan larangan-Nya. Bukan jalan orangorang yang mendapat murka, yang kehendak mereka telah rusak, sehingga meskipun mereka mengetahui kebenaran, namun menyimpang dari kebenaranNya.Bukan juga jalan orang-orang yang sesat, yaitu orang-orang yang tidak memiliki ilmu pengetahuan, sehingga mereka berada dalam kesesatan serta tidak mendapatkan jalan menuju kebenaran. Pembicaraan di sini dipertegas dengan kata "la" (bukan), guna menunjukkan bahwa di sana terdapat dua jalan yang rusak, yaitu jalan orang-orang Yahudi dan jalan orang-orang Nasrani. Juga untuk membedakan antara kedua jalan tersebut, agar setiap orang menjauhi diri darinya. ${ }^{41}$

${ }^{41}$ Lihat, Ibid., h. 35-36 


\section{Penutup}

Wujud ibadah sejati akan terlihat pada diri seorang hamba, manakala ia melakukannya dengan ketulusan, yaitu melakukan ibadah hanya karena Allah Swt. Ibadah seperti itu adalah ibadah yang telah berhasil bagi seorang hamba dalam meraih kedekatan kepada Allah Swt. Kedekatannya kepada Allah Swt., akan melahirkan kedamaian dan kebahagiaan serta kemudahan dalam menghadapi berbagai persoalan untuk dijawab dan berbagai permasalahan untuk diselesaikan.

Kemudahan-kemudahan di atas terjadi pada diri seorang hamba karena pemahaman tentang Iyyaka-Nabudu dan Iyyaka-Nastain yang professional dan propossional. Pemahaman yang duduk (professional) dan penerapan pemahaman yang tepat (propossional) terhadap kajian Iyyaka-Nabudu dan Iyyaka-Nastain pada diri seorang hamba dalam menghadapi hidup, maka akan meluruskan niat dan tujuannya. Kelurusan niat dan tujuan akan memperjelas bagi seorang hamba di dalam melakukan setiap bentuk aktivitas kehidupannya selama di dunia, sebab ia lakukan dengan Bismillah dan hasilnya selalu diucapkannya dengan Alhamdulillah. Kedua ucapan tersebut adalah bentuk dari penuhan seorang hamba hanya kepada Allah Swt., yang sebagai Sosok yang disembahnya dan Sosok tempat ia meminta.

Kajian di atas telah menerangkan kepada seorang hamba bahwa kedamaian dapat terwujud bila pemahaman tentang surat al-Fatihah didudukkan secara professional dan propossional. Kedamaian tersebut terwujud karena kedekatan seorang hamba kepadaAllah Swt., dan dijelaskan dengan lugas di dalam surat alFatihah yang menjadi istimewa dari surat lainnya dan disebut di antaranya dengan sebutan "Ummul-Qur'an", yaitu induk Alquran dan menjadi bagian dari rukun shalat.

\section{DAFTAR PUSTAKA}

Abdul Qadir Isa, Syekh, Hakekat Tasawuf, terj. Khairul Amri, Harahap dkk, (Jakarta: Qisthi Press, 2017), cet. Ke-15

Abdurrahman Hasan Alu Syaikh, Syaikh, Fathul Majid, terj. Ibtidąin Hamzah dkk, (Jakarta: Pustaka Azzam, 2012)

Al-Jauziyyah, Ibn Qayyim, Madārij al-sālikīn fì tafsīri iyyāka na̧buduwaiyyāka nastaīn, jld I

Tahdzibu Madariju as-Salikin,Hadzbahu; Abd al-Munim Shalih al-Ali a-Izzy, jld. I, (Beirut Libanaon; Muassastu ar-Risalah, 2000) 
, Al-Fawaid,tahqiq: Ishomuddin as-Shibabati, (Al-Qahirah: Dar- al-Hadis, 2005)

Andy, Safria, Hati (Qalb) dalam Pemikiran Tasawuf Ibn Qayyim Al-Jauziyyah, Disertasi, (Medan: PPs IAIN Medan-Sumatera Utara), 2012. ,Nilai-nilai Tasawuf dalam Surat Al-Fatihah,Jurnal Hikmah, Volume V N0 1 Jan - Des 2017, Prodi. Agama dan Filsafat Islam, Fak.Ushuluddin dan Studi Islam UIN-SU, 2017.

Ar- Rifaii, Muhammad Nasib, Ringkasan Tafsir Ibnu Katsir, (Jakarta:Gema Insani, 1999)

,Ringkasan Tafsir Ibn Katsir, Jilid. I, terj.Syihabuddin, (Jakarta: Gema Insani, 2012)

As-Suyuti,Imam Jalaluddin al-Mahalli dan Imam Jalaluddin, Tafsir Jalalain, Jilid.1, terj. Bahrun Abu Bakar, (Bandung: Sinar Baru Algensindo, 2010), cet. Kedelapan,

Halim Hasan Daulay, H. A, dkk, Tafsir Alquran Alkarim, (Medan : Yayasan Persatuan Amal Bakti, 1967), cet. IX,

Muhammad bin 'Abdurrahman bin Ishaq Alu Syaikh, „Abdullah bin, (Pentahqiq/Peneliti), Tafsir Ibn Katsir,Jild. I, terj. (Bogor : Pustaka Imam Asy-Syafi'I, 2004), cet. V,

Mustofa, H. A, Akhlak Tasawuf, (Bandung; Pustaka Setia, 2005)

Nata, Abuddin, Akhlak Tasawuf(Jakarta; Rajawali Pers, 2010)

Uwaysi an-Nadawi, Muhammad, Tafsir Qayyim li Ibn Qayyim, Maktabah asSyamilah. 